\title{
A (not so) distant mirror: Koreans' opinions about the impact of Korean culture in Romania
}

\author{
Valentina MARINESCU ${ }^{1}$
}

The present paper aimed to identify the ways in which the members of the Korean diaspora in Romania assessed the Romanian economy and society. The research project used the method of interview applied on a sample of seven Koreans settled in Romania. As the analysis showed, the image of the Romanian economy and society among members of Korean diaspora in Romania is a balanced one. It contains both positive and negative elements. 'Respect' was the main value that was assessed as important to be 'exported' from South Korea to Romania. Mass media were recognised as the main 'vehicles' for the introduction of South Korean popular culture. The success of Hallyu also had a positive influence on the economic relation between Romania and South Korea.

Key-words: Korean diaspora in Romania, opinions, Romania, Hallyu, diplomatic relations.

\section{Introduction}

The issue of Korean diaspora and the analysis of its development and activities in different regions of the world has become a topic of interest in recent years (Bergsten, Choi, Ch'oe and Choe 2003; Lee 2005; Lee 2009; Tsuda and Song 2018; Yoon 2012). In Europe, the research made by Brubaker and Kim (2011) and Kim (2018) pointed out the peculiarities of Korean diaspora, the similarities and differences of those diasporic groups as compared to others from Latin America or Australia.

In the case of Eastern Europe we can notice that the Korean diaspora was studied mainly in countries such as Hungary (Kim 2014) or Germany (Lee 2005). Given the changes that took place in the last years as the result of Hallyu's success in this part of the world (Marinescu 2014), we were interested to study the Korean diaspora from Romania, a country where the importance of Hallyu is obvious (Marinescu and Balica 2013).

${ }^{1}$ University of Bucharest, vmarinescu9@yahoo.com 
The 'Korean Wave' or Hallyu, is a phenomenon which refers to the current impact of the products specific to Korean popular culture (films, music, games, fashion) worldwide (Ryoo 2009; Kim 2013; Kuwahara 2014; Bok-rae 2015). The 'export' of Korean products was made first in Asian countries (Chua and Iwabuchi 2008; Yang 2012) and in the last decades it reached Europe and North America (Elaskary 2018; Jin and Yoon 2016). Hallyu's emergence and development in Eastern Europe was linked to the broadcast of Korean TV series on the main TV stations and the dissemination of K-Pop music occurred both through traditional media and on the Internet (Marinescu and Balica 2013; Marinescu 2014).

In Romania, the Korean community consists of about 1,000 people, permanently settled or temporarily moving in this country, mainly to develop a business and for economic-related purposes. As compared to other ethnic communities, the Korean community is a rather small one, its existence being made possible by the establishment of diplomatic relations between Romania and South Korea in 1990 (Ministerul Afacerilor Externe 'Ministry of Foreign Affairs' 2021)

The present paper aimed to identify the ways in which the members of the Korean diaspora assessed the Romanian economy and society. We aimed to respond to the following research questions:

1) Are the Koreans' opinions about Romania and Romanians positive or negative?

2) What are the main traits of the Romanian society according to Koreans living and acting in Romania?

3) What Korean values can be 'exported' to Romania?

\section{Methodology}

To gather the data for this research we chose to use a qualitative method: the interview. The interview offers the respondent the opportunity to show his or her personality or to express his or her own opinions in a free way (Hollway and Jefferson 2000). At the same time, the researcher who uses the interview as a research method is able to obtain more information about a topic of interest (Gubrium and Holstein 2001).

In making our interviews we had to surpass two major issues. One of them was the difficulty of having face-to-face meetings, due to the fact that, in the beginning, the respondents were uncertain of the purpose of the interview. The second problem was linked to the recording of the interviews and ethical issues related to General Data Protection Regulation - GDPR (Intersoft Consulting 2021). 
To overcome the last issue, each respondent filled an individual agreement concerning data protection.

The interview guide for the Korean citizens was made up of fourteen open questions. The respondents were asked to provide information, as detailed as possible, about the reasons of choosing Romania as a country of emigration, the problems they faced immediately after moving in our country, their (past and present) opinions and perceptions about Romanian society, the opinion about their future in our country, to name the main values which could be 'exported' by South Korea, and to indicate the things they missed when they were thinking about South Korea.

In the case of our small research project, the sample was made up of seven Koreans who have settled in our country. We chose people who perform different activities in order to be able to observe how the environment in which they carry out their work can influence their perception about Romanians and the Romanian society.

The respondents in the sample have lived in Romania for more than three years, they are all middle aged, and have businesses with activities that put them into close contact with the Romanian economic system and legislation. The average age of the interviewees was 44 years, with a standard deviation of 2.33. The youngest person who agreed to be interviewed was 29 years old, while the oldest was 55 years of age.

The structure of the sample was the following:

Table 1. Structure of the sample of the members of Korean diaspora in Romania

\begin{tabular}{|l|l|l|}
\hline $\begin{array}{c}\text { Symbols used } \\
\text { for subjects }\end{array}$ & \multicolumn{1}{|c|}{ Age } & \multicolumn{1}{c|}{ Activity } \\
\hline K1 & 40 years & Owner of a Korean restaurant \\
\hline K2 & 29 years & Professor \\
\hline K3 & 52 years & Engineer and professor \\
\hline K4 & 49 years & Owner of a shop with Korean products \\
\hline K5 & 39 years & Chief of the department in a Korean firm \\
\hline K6 & 49 years & $\begin{array}{l}\text { Owner of a business in the field of construction, equipment } \\
\text { manufacturing and distribution of products }\end{array}$ \\
\hline K7 & 55 years & Owner of a Korean restaurant \\
\hline
\end{tabular}

\section{Analysis of the results}

In the beginning, the members of the Korean diaspora living in Romania had a vague general knowledge about the country, that was somehow blurred by images and myths spread by the mass media. Thus, the only information about Romania 
that our respondents had before they moved here was related to famous Romanian sportsmen. Several respondents told us that, when they lived in South Korea, they heard about Nadia Comăneci and Gheorghe Hagi. They also mentioned the fact that when they imagined Romania in the past, they also made an instant connection with Dracula's bloody story, without knowing anything about the real history and culture of the country. Some of the interviewees had also mentioned political issues, telling us that before 1989 , in Romania there was a communist regime in power and after 1990 democracy was installed.

The main reasons for moving to Romania were the changes that took place after 1990. All Koreans interviewed mentioned the opening of borders, the opportunities for foreign citizens, and the existence of an open market economy as main reasons for their decision to move to this country. Most of the respondents came to Romania to search for market opportunities, to seize and take advantage of the new business developments. One can notice that all respondents were businessmen who own either a Korean restaurant or shops that sell Koreanimported goods. As the main reason for moving from South Korea to Romania they invoked either the existence of an untapped market segment during the '90s or the seizing of new opportunities in other parts of the world.

The interviewees' perception of the Romanian national economy remained positive after they decided to come to this country. All Koreans interviewed had stated that in recent years, the Romanian economy has grown very much and at a rapid pace. In a direct connection with this positive assessment they saw Romanians as good entrepreneurs and smart people. One of them even cited the data from European studies on entrepreneurship as a basis of his assessments.

When asked about the existing legal framework for settling and managing of their business, the Korean respondents have assessed that the existence of many regulations made it extremely difficult for a foreign company to operate in Romania. Also, they added, they could understand the fact that Romania was aligned to the European requirements of taxation but in their opinion, this is not a positive fact. As one respondent pointed our, the complex framework meant also higher taxes and those tax burdens for their business could impede the 'normal' economic activities.

A negative aspect of Romanian society that was mentioned during the interviews was bureaucracy. Our interviewees had declared that bureaucracy in our country was interested only in 'formal' aspects of the work. In their words, the state employees were focused exclusively on collecting information, following the payment of taxes and submission of documents, and paid little attention to the economic activities. As one Korean respondent (K4) noticed, "sometimes a single 
document necessary for a company had to be approved by more than four public institutions and five departments".

The members of the Korean diaspora comprised in our study assessed that 'bribery' was a very serious problem in Romania, with a relevant impact on the quality of services. Our interviewees also stressed the fact that in recent years, due to the changes in the Romanian judicial system, bribery was no longer possible in many public institutions, but remained a reality at the level of interpersonal relations.

When the respondents were asked about the general image of Romania in South Korea, they agreed that the perception of Romanian society was positive. Overall, the Koreans we had interviewed had characterised Romanians as hardworking people, who also have a high sense of responsibility. Despite the fact that they also knew that Europeans did not have a very positive image of Romanians, the Koreans with whom we discussed have emphasized that this European opinion was wrong. The main arguments they used to counter misconceptions about Romania were twofold. On one hand, they invoked the fact that many important European politicians entered marriages with Romanians and, on the other they stressed the complete lack of racial-hate events in Romania. According to one of our respondents (K3), due to the fact that the Romanians did not have any racial problems and did not treat Korean citizens as 'possible enemies', any Korean businessman will find an easier way to enter commercial and human relations with them.

Religion was another element mentioned as a basis to establish positive personal relations with Romanians. One member of the Korean diaspora who was interviewed (K5) told us that he had a personal preference to collaborate with people who practice religion because he perceived them as 'trustworthy' persons.

At a certain point in our discussions, the Koreans invoked the Romanians' desire to know more about the Korean culture. One explanation they found for this was the gastronomic culture, which made Romanians open to experiment and able to understand a foreign culture with the help of their 'taste buds'. At the beginning, our respondents pointed out that the Korean food and products they sell were considered by Romanians to be 'Chinese', but this initial perception had changed very quickly. Our Korean respondents noticed the positive and rapid customers' reception of the food and products they sold. Moreover, they noticed that, at present, Romanians easily identify the specific elements of Korean culture, those traits that make it unique.

According to our interviewees, Romanians, in general, perceive Asian cultures as exotic and they seemed to have an 'innate and developed desire' to know more about traditions, customs, language, and other aspects related to contemporary South Korean art. An important factor that influenced the 
Romanians' appetite to know more about Korean culture was mass media, as acknowledged by all our respondents. As an interviewee told us (K2), after Romanian television stations started to broadcast Korean historical TV series and contemporary Korean music (especially K-Pop), the Romanians became more interested to buy Korean goods or to go to Korean restaurants.

At the personal level, the first difficulty encountered in Romania by our respondents was obtaining the residence permit. In our discussions they acknowledged that the procedure was extremely difficult and complicated, even if in recent years it was digitalised. Another difficulty mentioned by them was the language, the high differences that exist between Romanian and Korean. All members of the Korean diaspora in Romania stressed the existence of linguistic discrepancy between them and Romanians, which could be surpassed only when they started to learn the Romanian language.

When asked about the negative traits of Romanians, our respondents pointed out the lack of economic initiative for many Romanians and their unwillingness to assume the leadership role in a group or related to an action. One explanation for those negative aspects was given by a Korean businessman (K5) who invoked the communist history of our country, a period in which the individual had no right at initiative, no property, and could not act in a personal way due to ideological reasons. Another respondent (K6) told us that he noticed a steady increase in Romanian empowerment, as well as willingness to take economic risks. He saw the capitalist transformation of Romania as a positive one and he also estimated that, in time, the balance between individual and collective economic goals would be achieved in our country.

In our discussions we also asked our respondents to analyse the main differences between Romanians and Koreans from human perspective. It did not come as a surprise for us that the Koreans living in Romania had indicated the organisational skills as the main point of difference between the two societies. Thus, Koreans saw Romanians as having a chaotic working program, an example given in this case being the lack of a lunch break, as was the case in South Korea. Speaking about other differences, the Koreans invoked a higher importance for gender equality at the workplace and within the society, on the one hand, and higher labour productivity for Romanians, on the other. When the issue of social hierarchy was discussed, our respondents highlighted the linguistic differences, which allowed to Korean language to present your respect towards any person (even if he or she is one year older than the speaker), stressing this is in stark contrast to Romanian language where the degrees of politeness are not so subtle.

'Intelligent', 'warm', 'optimist' and 'friendly' were the main positive traits of Romanians as mentioned by our Korean respondents. On the other hand, the 
members of Korean diaspora saw Romanians as people who do not assume responsibilities, as 'frivolous' (K3), 'individualistic' and 'unwilling to work in a team and favouring personal goals' (K2).

In our discussions we also asked what they think about the Korean society's values that could be borrowed by Romanians. According to our respondents, those values were mainly related to the human nature of social realities. Thus, the Koreans we interviewed had stated that Romanians could learn to pay higher respect to the elderly people, to be more attentive to the changes in general politics or in their workplace, and to be more responsible and organised in the daily life. Other elements brought to our attention were the development of benevolence and mercy towards others, which had to be a part of children's primary education, like in South Korea. Given the character of their business, it was not surprising that our interviewees had indicated the change of eating habits as one domain in which Romanians could learn from Korea. One respondent (K1), who owned a Korean restaurant, said that he argued in favour of adopting more discipline with regard to daily meals by eating more vegetables and fruits on a regular basis. Other answers to our question made reference to the fact that 'Romanians should become more attentive to the quality of the clothes, especially the underwear' (K4), to the 'quality of goods they use in their house' (K6), and even to the adoption and implementation of reforms inspired from the Korean education system.

At the end of our dialogue, the members of the Korean diaspora in Romania told us about the way in which South Korea had had an influence on the lives of Romanian fans. All our respondents stressed the fact that any person who is passionate about Korean culture, involuntarily began to borrow many Korean attitudes and behaviours. In their words, Romanian fans of Hallyu were 'openminded', 'young people with a great desire to prove what they can' (K3). We can detect a high praise for Romanian fans of Hallyu, our respondents declaring that they were eager to share their experiences and thoughts with them. As one businessman told us (K1), the main reason of his positive attitude toward Romanians' passion for Korean culture was his belief that they had a wider worldview and, as such, could have more alternatives for success in the future, at home or abroad.

\section{Conclusions}

As our analysis showed, the image of Romanian economy and society among members of the Korean diaspora living in Romania was a balanced one. This image 
is a sort of 'mirror', which contained both positive and negative elements. 'Respect' was the main value assessed as relevant to be 'exported' from South Korea to Romania. As it is well-known (Sung and Kim 2003; Sung 2004) 'respect' in Korean culture is directly related to Confucianism and has deep historical roots in this society. It was not a surprise that, although Koreans from our country considered Romanians as 'welcoming' and 'cheerful' people, they had all noticed the lack of respect for others, especially for the elders, as the main negative characteristic of people from our country. According to the members of Korean diaspora comprised in our sample, other values worth to be 'imported' in Romania were: discipline, the acceptance of risks (especially related to economic activities), and organisation.

Our respondents also pointed out positive traits of the Romanian society ('economic development', 'lack of prejudice', 'hard-work'), as well as negative ones ('excessive bureaucracy' and the existence of 'bribery'). Romanians were characterised as 'open-minded', 'curious', 'friendly' and 'religious', and our interviewees noticed their ability to enter and maintain social relations with foreigners.

Mass media were recognised as the main 'vehicles' for the introduction of South Korean popular culture, and in this way the previous results of research studies (Balica and Marinescu 2013; Marinescu 2014) conducted in Romania on Hallyu were confirmed. In addition, mass media were considered by the Koreans living in Romania as an important instrument in opening the Romanian internal market for South Korean products.

We are aware of the fact that our analysis has certain limitations, the most important being the small size of the sample and the fact that it was centered only on the Romanian case.

Despite these shortcomings, we consider that our small research project sheds light on an important aspect of the relations between South Korea and Romania, namely the role played by the Korean diaspora in promoting the culture of Korea.

\section{References}

Chua, Beng Huat and Koichi Iwabuchi (eds.). 2008. East Asian Pop Culture: Analysing the Korean Wave. Vol. 1. Hong Kong: Hong Kong University Press.

Bergsten, C. Fred and Inbom Choi (eds.). 2003. The Korean Diaspora in the World Economy (Vol. 15). Washington, DC: Institute for International Economics.

Bok-rae, Kim. 2015. "Past, Present and Future of Hallyu (Korean Wave). American International Journal of Contemporary Research 5 (5): 154-160. 
A (not so) distant mirror: Koreans' opinions about the impact of Korean culture in Romania 85

Brubaker, Rogers and Jaeeung Kim. 2011. "Transborder Membership Politics in Germany and Korea. European Journal of Sociology/Archives Européennes de Sociologie 52 (1) : 21-75.

Elaskary, Mohamed. 2018. "The Korean Wave in the Middle East: Past and Present." Journal of Open Innovation: Technology, Market, and Complexity, 4 (4): 51. https://doi.org/10.3390/joitmc4040051 (Accessed on October, 10th, 2021).

Gubrium, James F. and James A. Holstein. 2001. Handbook of Interview Research: Context and Method. London: Sage Publications.

Hollway, Wendy and Tony Jefferson. 2000. Doing qualitative research differently: Free Association, Narrative and the Interview Method. London: Sage Publications.

Intersoft Consulting. 2021. General Data Protection Regulation - GDPR. Available at: https://gdpr-info.eu/ (Accessed on October 9, 2021).

Kim, Bogook. 2014. "Forgotten Era, Forgotten People: The North Korean Diaspora." Hungarian Studies 28 (2): 255-273.

Kim, Helen. 2018. "Being 'Other' in Berlin: German Koreans, Multiraciality, and Diaspora." Journal of Citizenship and Globalisation Studies 2 (1): 63-74.

Kim, Youna (ed.). 2013. The Korean Wave: Korean Media Go Global. New York: Routledge.

Kuwahara, Yasue (ed.). 2014. The Korean Wave: Korean Popular Culture in Global Context. New York: Palgrave Macmillan.

Jin, Dal Yong and Kyoong Yoon. 2016. "The Social Mediascape of Transnational Korean Pop Culture: Hallyu 2.0 as Spreadable Media Practice. New media \& society, 18 (7): 1277-1292.

Lee, Hye-Kyung. 2005. "The Korean Diaspora and Its Impact on Korea's Development." Asian and Pacific Migration Journal 14 (1-2): 149-168.

Lee, Helene Kim. 2009. Bittersweet Homecomings: Ethnic Identity Construction in the Korean Diaspora. Santa Barbara, Ca.: University of California.

Marinescu, Valentina. 2014. The Global Impact of South Korean Popular Culture: Hallyu Unbound. London, New York: Lexington Books.

Marinescu, Valentina and Ecaterina Balica. 2013. "Korean Cultural Products in Eastern Europe: A Case Study of the K-Pop Impact in Romania." Region: Regional Studies of Russia, Eastern Europe, and Central Asia 2 (1): 113-135.

Ministerul Afacerilor Externe (Ministry of Foreign Affairs). 2021. Republica Coreea (South Korea). Available at: https://www.mae.ro/bilateral-relations/2042 (Accessed on October 10, 2021).

Ryoo, Woongjae. 2009. "Globalization, or the Logic of Cultural Hybridization: The Case of the Korean Wave." Asian Journal of Communication 19 (2): 137-151. 
Sung, Kyu-taik. 2004. "Elder Respect Among Young Adults: A Cross-Cultural Study of Americans and Koreans." Journal of Aging Studies 18 (2): 215-230.

Sung, Kyu-taik and Han-sung Kim. 2003. "Elder Respect Among Young Adults: Exploration of Behavioral Forms in Korea." Ageing International 28 (3): 279-294.

Tsuda, Takeuky and Changzoo Song (eds.). 2018. Diasporic Returns to the Ethnic Homeland: The Korean Diaspora in Comparative Perspective. Switzerland: Springer.

Yang, Jonghoe. 2012. "The Korean Wave (Hallyu) in East Asia: A Comparison of Chinese, Japanese, and Taiwanese Audiences Who Watch Korean TV Dramas." Development and Society 41 (1): 103-147.

Yoon, In-Jin. 2012. "Migration and the Korean Diaspora: A Comparative Description of Five Cases." Journal of Ethnic and Migration Studies 38 (3): 413-435. 